Article

\title{
Comparative Analysis of Factors for Supplier Selection and Monitoring: The Case of the Automotive Industry in Thailand
}

\author{
Juthathip Suraraksa and Kwang Sup Shin * \\ Graduate School of Logistics, Incheon National University, Incheon 22012, Korea; juthathip@inu.ac.kr \\ * Correspondence: ksshin@inu.ac.kr
}

Received: 21 January 2019; Accepted: 10 February 2019; Published: 14 February 2019

check for updates

\begin{abstract}
The integration of the global market makes the supply chain more complex and has great impacts on efficient supplier management strategies. The aim of this study is to present a systematic supplier management framework to integrate supplier selection and monitoring phases, which are not independent of each other. However, only a few previous studies have pointed out the differences between the two phases. The proposed methodology integrates a quantitative and qualitative approach, formulating multi-criteria decision making (MCDM) using the analytic hierarchy process (AHP) to evaluate the priorities of these criteria. This research explores the difference in the set of criteria for supplier selection and supplier monitoring. The results provide comprehensive insights into the criteria to help decision-makers, managers, and practitioners select appropriate suppliers and monitor suppliers' performances in the automotive industry. Based on the result, it can be said that a company should integrate the supplier selection and monitoring process. Furthermore, the purchasing and manufacturing manager should continuously collaborate and synchronize the relative weights for the critical factors.
\end{abstract}

Keywords: supplier selection; supplier monitoring; supply chain; sustainable supplier management; analytic hierarchy process (AHP); automotive industry

\section{Introduction}

Generally, most previous research categorizes supply chain management (SCM) into the following three major parts: purchasing, manufacturing, and distribution [1]. The purchasing function focuses on obtaining raw materials for manufacturing, which is an essential component to start supply chain execution [2]. Furthermore, the quality of products depends on the supplier procured by the purchasing process. In particular, manufacturing companies spend about $70 \%$ of the cost on purchasing materials from suppliers [3]. In addition, the purchased percentage in an average OEM's (Original Equipment Manufacturer) material content is approaching $70 \%$, with many OEMs exceeding $80 \%$ [4]. This means that the unit cost is highly dependent on suppliers. Therefore, purchasing can be regarded as one of the most important activities [3,5]. It should be considered as the essential strategy for producing a high quality at a low cost to manage the relationship with suppliers.

Globalization of the supply chain enables securing any materials from the worldwide market [6]. It is the most challengeable decision making in outsourcing, which plays a critical role in the success of a supply chain [7]. Outsourcing has become one of the essential requirements of companies to obtain some of the products and services for supporting manufacturing. It has also served as a strategy to reduce costs and enhance companies' competitive capabilities [8]. However, outsourcing many components to manufacturing companies' suppliers can lead to a high complexity and uncertainty in the business environment, such as financial crisis (bankruptcy), critical impacts from environmental disasters (floods, hurricanes, and tsunamis), and social issues (worker protests). 
Furthermore, suppliers play an important role in implementing sustainable supply chain initiatives and in achieving economic, social, and environmental gains [9]. Sustainable supplier management (SSM) has been interrelated with essential purchasing function; however, the operations, such as sustainable supplier selection, sustainable supplier monitoring, and sustainable supplier development, are independent [10]. Therefore, supplier selection is a vital issue and a significant strategic decision in the management of a sustainability-focused supply chain $[9,11]$. Furthermore, supplier monitoring is an essential process in enhancing the overall supply chain performance while achieving the goal of SSM [12].

However, a great deal of previous research has focused on how to select the appropriate suppliers by presenting different frameworks. Therefore, few studies have compared and analyzed the difference of factors between supplier selection and monitoring [10]. In this context, the present study develops a decision-making framework for supplier selection and supplier monitoring. This framework can be divided into the following three steps. The first step is the identification of the main dimensions and important criteria for selecting and monitoring. As the second step, the main dimensions and criteria are prioritized. Thirdly and finally, a comparison of the criteria is performed. In the present study, we propose a novel framework to understand the differences between supplier selection and monitoring. The sets of criteria and their relative weight are obtained by using the analytic hierarchy process (AHP). The ranking and the relative weight, which are secured from the automobile manufacturing industry in Thailand, are then compared.

Over the last fifty years, Thailand's automotive industry has undergone considerable development to become one of the major industries in Thailand [13]. The industry accounts for about $12 \%$ of Thailand's gross domestic product (GDP) and employs more than 500,000 people, including the OEM and Tier 1, 2, and 3 suppliers [14]. Thailand is the largest automotive parts exporter and automobile manufacturer in the Association of Southeast Asian Nations (ASEAN) [15]. In addition, Thailand was ranked the second biggest automobile exporter in Asia in 2015. More than $60 \%$ of the 100 largest suppliers for parts of vehicles in the world have their production hubs in Thailand [13]. Furthermore, 18 leading global vehicle assemblers in Japan, the United States, Europe, and China have their own manufacturing facilities in Thailand. These companies are connected with more than 700 suppliers and 1,700 supporting companies in Thailand [13].

The automotive industry has become one of the most important to Thailand's economic growth. By 2020, Thailand aims to manufacture over 3.5 million units of vehicles to become one of the top performers in the global automotive market [16]. By 2021, it is expected that Thailand will become the global hub for green automotive production with advanced technologies [13]. As the country continues to expand its manufacturing base, auto part suppliers are boosting their presence in the market [16]. Moreover, local manufacturers support over $80 \%$ of the parts in auto vehicle production [13]. Therefore, the factors for selecting and monitoring to increase the efficiency of purchasing in strategic operations need to be considered. Overall, Thailand's auto part suppliers have always been a strong supporting factor contributing to the fast growth of Thailand's automotive industry [13]. In addition, the challenge of auto assemblers in Thailand requires the ability of the supplier to fulfill all requirements and satisfaction from the customers.

The main contribution of the present study is four-fold. First, we design a framework for selecting and monitoring suppliers to provide seamless operations in the supply chain. Second, it is shown that the proposed framework can be applied to increase the efficiency of procurement in the field of the automotive industry. Third, we explore the differences in criteria for supplier selection and supplier monitoring. Fourthly and finally, our results provide useful insights about the way to enhance collaboration between purchasing and manufacturing department, particularly in the automotive industry. This may help organizations to better understand the interrelated process in supplier management.

The remainder of this paper is organized as follows. Section 2 provides a review of relevant literature. Then, in Section 3, we outline the proposed research framework. The results of the 
comparative analysis are presented and discussed in Section 4. Finally, contributions of the present study, its limitations, and directions of future research are discussed in Section 5.

\section{Literature review}

\subsection{Sustainable Supplier Selection}

The importance of the supplier selection process lies in helping organizations to achieve the maximum ecological-economic benefit $[9,17]$. Generally, the supplier selection process consists of several stages. First, the process starts with identifying needs and specification. Then, criteria are formulated. After that, managers or decision makers identify a group of qualified suppliers. Finally, evaluation and final selection are performed [10].

Sustainable supplier selection aims to identify and evaluate appropriate suppliers that perform the best along the upstream supply chain in terms of economic, social, and environmental dimensions $[10,18,19]$. However, the criteria for supplier selection largely depend on individual companies and industries. Therefore, the identification of supplier selection criteria should be generated by specific environments and mainly requires domain experts' assessment and evaluation [11].

According to Sagar and Singh [20], supplier selection criteria change over time, depending on the political, economic, social, and environmental characteristics of the business. In addition, Sagar and Singh [20] proposed the following 21 essential criteria used in the automobile sector: Price, Quality, Quality Standards, Reputation and Position in Industry, Delivery, Financial Position, Quality System Adequate, Technical Capability, Production Facilities and Capacity, Long-Term Relationship, Trust, Procedural Compliance, Responsiveness, Impression, Communication System, Warrantees and Claim Policies, ISO 9000 / ISO 14000 certified, Attitude, Management and Organization, Packaging Ability, and Performance History.

Several studies have defined supplier selection and evaluation criteria as a multi-criteria decision-making problem. Furthermore, previous research has also used the AHP-based decision-making approach to solve the supplier selection problem. For instance, Muraldiharan, Anantharaman, and Deshmukh [21] presented a five-step AHP-based model with the following nine criteria: Quality, Delivery, Price, Technical capability, Financial position, Past performance attitude, Facility, Flexibility, and Service for rating and selecting suppliers in a leading manufacturing bicycle. Moreover, experts from different functions were involved in the selection process.

Hou and Su [22] proposed an AHP-based decision support system to select and evaluate potential suppliers. External and internal factors were considered under the changing global environment. Quality, Cost, Technology, Production capability, Research and Development (R\&D), Delivery \& Location, and Performance \& Service are used to solve the supplier selection problem in mass customization, such as a printing manufacturer.

Furthermore, Dweiri, Kumar, Khan, and Jain [23] applied an AHP-based decision system in supplier selection in the automotive industry in Pakistan. Suppliers were selected and ranked based on a set of sub-criteria. The results of the ranking showed that the main criteria, in descending order of importance, are price, quality, delivery, and service.

Shen, Muduli, and Barve [24] presented the usefulness of the appropriate implementation approach and continuous improvement in green supply chain management (GSCM) practice in the Indian mining sector. AHP was applied to evaluate the competitive priorities, and it was argued that interested organizations can use it as procedural guidance for GSCM implementation.

In their review of 143 papers, Zimmer et al. [10] highlighted that the most common methods in sustainable supplier management are Fuzzy Logic (31.1\%), AHP (18.8\%), and ANP (11.4\%). The authors suggested that future research should not only develop acceptable and comparable indicators, but also explore how to handle sensitive data. In supplier monitoring, common indicators of specific industries should be developed to help supplier selection and performance comparisons. Furthermore, experts from different companies and stakeholders should participate in this process using methods such as AHP, ANP, Fuzzy, or Delphi, to find, rank, and develop industry-specific criteria and indicator sets. 


\subsection{Sustainable Supplier Monitoring}

A long-term partnership between buyers and suppliers is essential in supply chain operations. In order to build such a relationship, buyers should continuously monitor suppliers' performances across multiple variables and provide feedback for improvement [5]. Supplier monitoring is an independent, but interrelated process, which follows the supplier selection process [12]. Furthermore, in order to be able to provide timely information to suppliers about buyers' expectations regarding efficiency, buyers should regularly measure and monitor the performance of suppliers concerning both tangible and intangible criteria [5].

In this respect, Zhang et al. [25] defined the following three significant challenges to improve the sustainability performance of an organization. First, assessment of sustainability requires consideration of not only economic, but also environmental and social, impacts. Second, it is necessary to find appropriate sustainability indicators and gather necessary data to quantify the sustainability performance. Thirdly and finally, sustainability should be seen in the context of the entire system. The authors focused on the evaluation of supply chain operations that maximize economic returns, minimize environmental impacts, and meet social expectations.

Talluri and Sarkis [5] argued that the supplier could be screened technically on several variables. Some of these variables are as follows: an emphasis on quality at the source; design competency; process capability; declining non-conformities; declining WIP; lead-time; space; flow distance; operators being cross-trained; doing preventive maintenance; operators able to present SPC and a quick set-up; operators able to chart problems and process issues; hours of operator training in TQC/JIT; concurrent design; equipment and labor flexibility; dedicated capacity; and production and process innovation.

Furthermore, Dey and Cheffi [26] specified many empirical criteria for green supply chain (GSC) performance measurement and proposed both qualitative and quantitative frameworks. The GSC performance is measured and benchmarked by using AHP. By integrating supply chain processes with organizational decision levels, both strategic and operational, the authors developed an innovative GSC performance measurement framework.

With the aim of constructing an overall index of sustainability, Yakovleva, Sarkis, and Sloan [27] proposed a possible way to combine quantitative statistical data with expert opinion. The authors developed sustainability indicators, conducted data collection, completed data transformation using rescaling, and determined the importance ratings using AHP. Stakeholders may use the index to evaluate and guide the sustainability performance in the food supply chain.

\subsection{SCORs, ISO 9001, and ISO 14001}

In the practitioner community, the Supply Chain Operations Reference (SCOR) model is a widely adopted approach employed to evaluate supply chain performance. This model defines business activities associated with all phases of satisfying a customer's demand [28]. The SCOR model consists of the following four sections: process, practices, people, and performance. In addition, there are six primary management processes: Plan, Source, Make, Deliver, Return, and Enable. The performance section of the SCORs model presents a hierarchical structure of performance metrics related to the following five attributes: Reliability, Responsiveness, Agility, Cost, and Asset Management Efficiency performance attributes $[2,28]$

Palma-Mendoza [29] presented an advantage of combining the SCOR model with the AHP. The SCOR model provided a standard and accepted the structure of supply chain metrics as a criterion for selection. Furthermore, managers familiar with this set of metrics are able to use their experience in the selection.

ISO 9001:2015 has become the leading industry standard to improve productivity and efficiency. Aiming to produce quality products and provide services, as well as to develop an effective quality management system (QMS), many organizations work towards adopting ISO 9001 [30,31]. There are two specific requirements for applying ISO 9001 in a company-namely, the ability to consistently provide products and the ability to enhance customer satisfaction through useful applications of the system [32]. 
In this connection, in a case study on the Brazilian automotive sector, Almeida, Pradhan, and Muniz [31] proposed a set of critical factors to support ISO 9001:2015 implementation based on AHP. The factors were deemed to be essential in the automotive industry to ensure that managers appropriately allocate resources during the implementation and maintenance of ISO 9001:2015. A new factor that was identified was quality staff reliability.

ISO 14001 is an international standard that assists managers to reduce the environmental impact [33]. The environmental management system (EMS) has become one of the main tools used by companies to handle environmental dimensions [34]. ISO 14001 consists of the following five main elements: environmental policy, environmental plan, implementation and operation of programs to meet objectives and targets, checking and corrective action, and management review [33]. Sambasivan and Fei [35] presented four factors and fourteen sub-factors that the authors argued to be critical for the effective implementation of ISO 14001-based EMS in the electrical and electronic sector in Malaysia. The AHP methodology was proved to be useful to find the relative weights and priorities of these factors and sub-factors [24,35].

In summary, from the literature review presented above, it can be concluded that many previous studies have explored the criteria for selecting suppliers and improving the sustainability performance of SCM. However, relevant research on the criteria for the monitoring supplier remains scarce. Few previous studies have focused on the sustainable supplier management context that takes into account the differences of factors between supplier selection and monitoring. To fill this gap in the literature, in the present study, we explore, compare, and analyze the criteria for supplier selection and monitoring. This study also considers SCORs, ISO 9001, and ISO 14001, which are the accepted standards in the structure of the supply chain in the automotive industry.

\section{Proposed Research Framework}

Figure 1 shows the three-step framework of the present study. Each step will be explained in further detail.

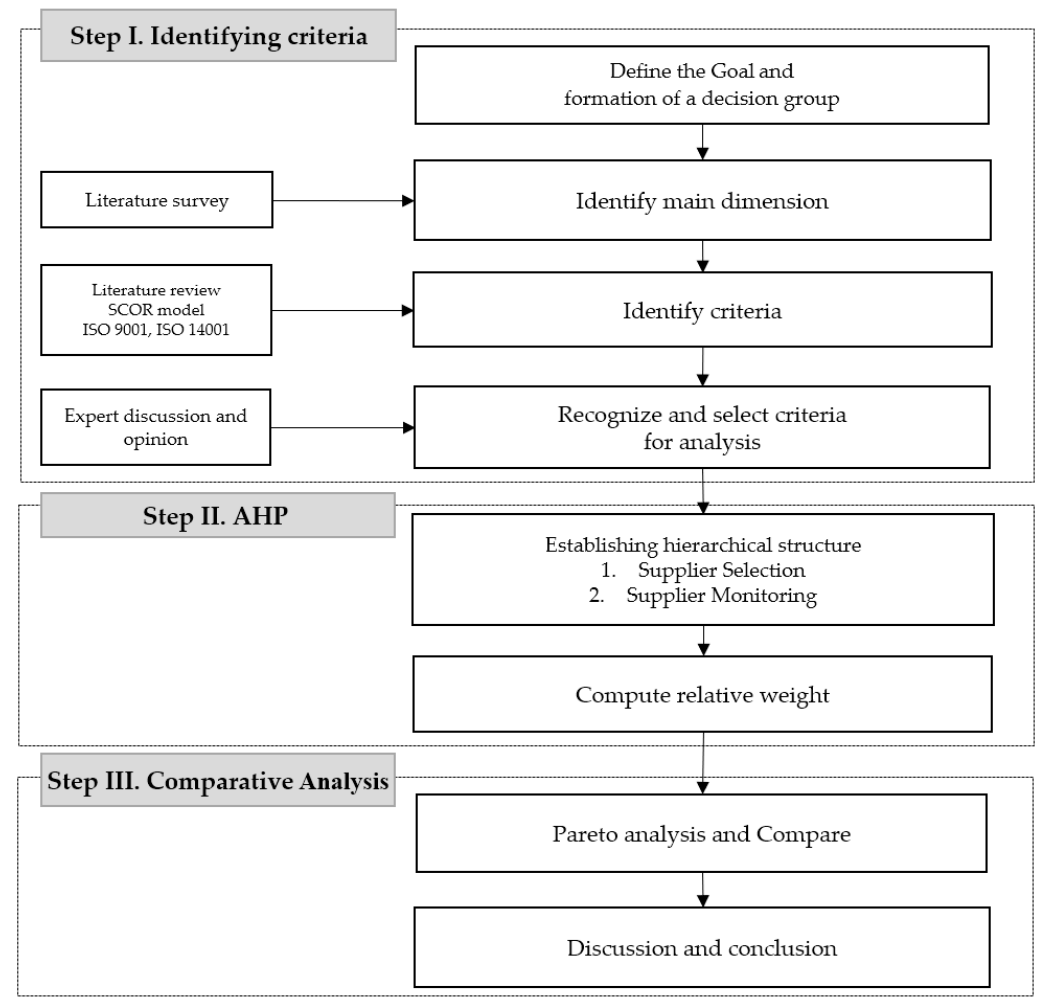

Figure 1. The proposed framework for supplier selection and monitoring. 


\subsection{Step I: Identify the Main Dimension and Criteria}

The first step is to identify the main dimension and related criteria [9]. The main dimension is identified by previous research [9-11,23,26,36-38]. Thereafter, the criteria are identified regarding the literature review, SCOR model, ISO 9001, and ISO 14001. Afterwards, all main dimensions and criteria are determined and recognized with three domain experts by using the Delphi method. In the first round, an open-ended questionnaire is used to gather specific information about supplier selection and monitoring in the automotive industry. In the second round, each participant receives a preliminary questionnaire and classifies the criteria for supplier selection and supplier monitoring. In the third round, domain experts receive a questionnaire to review and revise the main dimensions and criteria based on the information provided in the first and second rounds. In the fourth round, the list of main dimensions and all criteria are submitted to experts until consensus on the factor for supplier selection and monitoring is reached. Finally, the list of main dimensions and all criteria are distributed to Step II.

\subsection{Step II: Compute Relative Weight for Criteria using AHP}

The analytical hierarchy process (AHP), introduced by Thomas L. Saaty in 1980, is one of the multi-criteria decision-making methods (MCDM). A pair-wise comparison of the criteria is applied to set priorities and make the decision to solve complex decision-making problems by evaluating multiple conflicting criteria.

An importance scale in the AHP method suggested making a pair-wise comparison among decision criteria following the importance scale shown in Table 1 [39]. According to the AHP methodology, consistency checking is considered to prove that the decision makers are rational. The level of inconsistency can be captured by a measure called the Consistency Ratio (CR) $[39,40]$. A value of CR below 0.1 is considered to be acceptable [40].

Table 1. Importance scale in the AHP method.

\begin{tabular}{cc}
\hline Scale. & Meaning \\
\hline 1 & " $i$ " is equally important to " $j$ " \\
3 & " $i$ is slightly more important than " $j$ " \\
5 & " $i$ " is more important than " $j$ " $j$ " \\
7 & " $i$ " is extremely more important to " $j$ " \\
9 & intermediate values \\
$2,4,6,8$ &
\end{tabular}

In the present study, the decision group consisted of 14 experts from eight automobile manufacturers in Thailand. The experts worked as senior managers, managers, and specialists in purchasing, production, supply chain, and manufacturing departments. They had a five-year or longer experience of working in the selection of and monitoring their suppliers. The survey was conducted between May and June 2018. A web-based AHP online system (AHP-OS) [41] was used as a multi-criteria decision-making tool.

Structurally, the present study was organized into two phases: the supplier selection phase and the supplier monitoring phase. The decision group had to make a pairwise comparison of all criteria in both phases. The example of a pairwise comparison to calculate the weight is shown in Figure 2. 


\section{Pairwise Comparison Supplier Selection}

Please do the pairwise comparison of all criteria. When completed, click Check Consistency to get the priorities.

AHP Scale: 1- Equal Importance, 3- Moderate importance, 5- Strong importance, 7- Very strong importance, 9- Extreme importance (2,4,6,8 values in-between).

With respect to Supplier Selection, which criterion is more important, and how much more on a scale 1 to 9 ?

\begin{tabular}{|c|c|c|c|c|}
\hline & \multicolumn{2}{|c|}{ A - wrt Supplier Selection - or B? } & Equal & How much more? \\
\hline 1 & - Cost & or $\bigcirc$ Quality & $\bullet_{1}$ & $\mathrm{O}_{2} \mathrm{O}_{3} \mathrm{O}_{4} \mathrm{O}_{5} \mathrm{O}_{6} \mathrm{O}_{7} \mathrm{O}_{8} \mathrm{O}_{9}$ \\
\hline 2 & - Cost & or $\bigcirc$ Capacity & $\bullet 1$ & $\mathrm{O}_{2} \mathrm{O}_{3} \mathrm{O}_{4} \mathrm{O}_{5} \mathrm{O}_{6} \mathrm{O}_{7} \mathrm{O}_{8} \mathrm{O}_{9}$ \\
\hline 3 & - Cost & or $\bigcirc$ Service & $\bullet_{1}$ & $\mathrm{O}_{2} \mathrm{O}_{3} \mathrm{O}_{4} \mathrm{O}_{5} \mathrm{O}_{6} \mathrm{O}_{7} \mathrm{O}_{8} \mathrm{O}_{9}$ \\
\hline 4 & - Cost & or OFinance & $\bullet_{1}$ & $\mathrm{O}_{2} \mathrm{O}_{3} \mathrm{O}_{4} \mathrm{O}_{5} \mathrm{O}_{6} \mathrm{O}_{7} \mathrm{O}_{8} \mathrm{O}_{9}$ \\
\hline 5 & - Cost & or OICT & $\bullet_{1}$ & $\mathrm{O}_{2} \mathrm{O}_{3} \mathrm{O}_{4} \mathrm{O}_{5} \mathrm{O}_{6} \mathrm{O}_{7} \mathrm{O}_{8} \mathrm{O}_{9}$ \\
\hline 6 & (- Cost & or OSustainability & $\bullet 1$ & $\mathrm{O}_{2} \mathrm{O}_{3} \mathrm{O}_{4} \mathrm{O}_{5} \mathrm{O}_{6} \mathrm{O}_{7} \mathrm{O}_{8} \mathrm{O}_{9}$ \\
\hline
\end{tabular}

Figure 2. Example of a pairwise comparison on AHP-OS.

\subsection{Step III: Compare and Analyze Different Criteria}

The Pareto analysis is one of the statistical techniques in decision-making applied to select a limited number of tasks that produce a significant overall effect [42]. It is a simple methodology used to determine which factors have more impact than others in an organization $[42,43]$.

From Step II, the decision group used a pairwise comparison to weight the factors. Then, the score of each factor was recorded by experts using AHP-OS. In this step, the Pareto analysis was applied to identify the set of important criteria that should be considered for supplier selection and supplier monitoring in the automotive industry. We then explored, compared, and analyzed the set of criteria for selecting supplier and monitoring based on the relative weights and priorities of criteria.

\section{Results and Discussion}

\subsection{Identify the Main Dimension and Criteria}

The main dimensions were 'Cost,' 'Quality,' 'Capacity,' 'Service,' 'Finance,' 'Information and Communications Technology (ICT),' and 'Sustainability.' The full set of criteria was divided into two sets (see Table 2). First, the set of criteria for selecting the supplier consisted of seven main dimensions (level 1) and 33 criteria (level 2). Second, the set of criteria for supplier monitoring also consisted of seven main dimensions (level 1) and 33 criteria (level 2). There were 21 criteria which appeared for both supplier selection and monitoring. Further, 12 criteria were categorized into the supplier selection phase. Another nine criteria were classified into the supplier monitoring phase. 
Table 2. The full set of criteria for supplier selection and supplier monitoring.

\begin{tabular}{|c|c|c|c|}
\hline Dimension & Criteria & Selection & Monitoring \\
\hline \multirow{3}{*}{ Cost } & Product cost & $\checkmark$ & $\boldsymbol{V}$ \\
\hline & Ordering cost & $\checkmark$ & $\checkmark$ \\
\hline & Logistics cost & $\checkmark$ & $\checkmark$ \\
\hline \multirow{7}{*}{ Quality } & Quality level & $\checkmark$ & $\checkmark$ \\
\hline & Investment in quality improvement & $\boldsymbol{\sim}$ & - \\
\hline & Certification \& quality assurance & $\boldsymbol{\sim}$ & - \\
\hline & ISO 9001 Implementation & $\boldsymbol{V}$ & - \\
\hline & Responsibility for product quality & - & $\checkmark$ \\
\hline & Responsiveness for product quality & - & $\checkmark$ \\
\hline & Orders defect rate & - & $\checkmark$ \\
\hline \multirow{9}{*}{ Capacity } & Manufacturing capability & $\boldsymbol{V}$ & $\checkmark$ \\
\hline & Technological capability & $\checkmark$ & $\checkmark$ \\
\hline & Flexibility in production & $\checkmark$ & $\checkmark$ \\
\hline & Inventory turnover & $\checkmark$ & $\checkmark$ \\
\hline & Employee turnover & $\checkmark$ & - \\
\hline & Capability enhancement & $\checkmark$ & - \\
\hline & Employee availability & - & $\checkmark$ \\
\hline & Time to Recovery (TTR) & - & $\boldsymbol{\sim}$ \\
\hline & Shortages of raw materials & - & $\checkmark$ \\
\hline \multirow{6}{*}{ Service } & Reliability of delivery service & $\boldsymbol{\nu}$ & $\boldsymbol{V}$ \\
\hline & Sharing of information & $\boldsymbol{\sim}$ & $\checkmark$ \\
\hline & Speed and timeliness of communication & $\checkmark$ & $\checkmark$ \\
\hline & Warranty & $\checkmark$ & - \\
\hline & Returns & - & $\checkmark$ \\
\hline & Accuracy of product and quantity delivered & - & $\boldsymbol{v}$ \\
\hline \multirow{5}{*}{ Finance } & Fixed Assets & $\boldsymbol{V}$ & $\boldsymbol{\nu}$ \\
\hline & Comparative balance sheet & $\checkmark$ & $\checkmark$ \\
\hline & Debt or credit rating & $\boldsymbol{\sim}$ & $\checkmark$ \\
\hline & Financial capability & $\checkmark$ & $\checkmark$ \\
\hline & Financial stability & $\boldsymbol{\sim}$ & $\boldsymbol{\sim}$ \\
\hline \multirow{5}{*}{ ICT } & Purchase order (PO) and payment system & $\boldsymbol{V}$ & $\checkmark$ \\
\hline & Production and scheduling system & $\boldsymbol{V}$ & $\checkmark$ \\
\hline & Inventory management system & $\boldsymbol{\sim}$ & $\checkmark$ \\
\hline & Barcode and RFID system & $\boldsymbol{V}$ & - \\
\hline & Enterprise Resource Planning (ERP) & $\boldsymbol{\sim}$ & - \\
\hline \multirow{7}{*}{ Sustainability } & Work safety and labor health & $\boldsymbol{V}$ & $\boldsymbol{V}$ \\
\hline & Employment practices & $\boldsymbol{\sim}$ & $\checkmark$ \\
\hline & Product design for environment (Eco-design) & $\boldsymbol{\nu}$ & - \\
\hline & Environmental management system & $\boldsymbol{V}$ & - \\
\hline & Investment in Research and Development (R\&D) & $\boldsymbol{\nu}$ & - \\
\hline & ISO 14001 implementation & $\checkmark$ & - \\
\hline & Contractual stakeholders influence & - & $\checkmark$ \\
\hline
\end{tabular}

\subsection{Computing Relative Weight for Criteria using AHP}

The results of the relative weighting are presented in Table 3. There were two phases, namely, the supplier selection phase and the monitoring phase. 
Table 3. The results of the relative weighting for supplier selection and supplier monitoring.

\begin{tabular}{|c|c|c|c|c|c|c|c|}
\hline Level 0 & Level 1 & Level 2 & $\begin{array}{l}\text { Global } \\
\text { Priority }\end{array}$ & Level 0 & Level 1 & Level 2 & $\begin{array}{c}\text { Global } \\
\text { Priority }\end{array}$ \\
\hline \multirow{34}{*}{$\begin{array}{l}\text { Supplier } \\
\text { Selection }\end{array}$} & & Product cost $(0.5860)$ & $13.24 \%$ & \multirow{34}{*}{$\begin{array}{l}\text { Supplier } \\
\text { Monitoring }\end{array}$} & & Product cost $(0.4560)$ & $6.67 \%$ \\
\hline & $\begin{array}{l}\text { Cost } \\
0259-1\end{array}$ & Ordering cost $(0.1855)$ & $4.19 \%$ & & Cost & Ordering cost $(0.1846)$ & $2.70 \%$ \\
\hline & 0.2259 & Logistics cost $(0.2285)$ & $5.16 \%$ & & 0.1463 & Logistics cost $(0.3594)$ & $5.26 \%$ \\
\hline & & Quality level (0.3739) & $11.21 \%$ & & & Quality level (0.3145) & $9.77 \%$ \\
\hline & Quality & Investment in quality improvement $(0.1620)$ & $4.86 \%$ & & Quality & Responsibility for product quality $(0.2464)$ & $7.66 \%$ \\
\hline & 0.2998 & Certification \& quality assurance $(0.3204)$ & $9.61 \%$ & & 0.3107 & Responsiveness for product quality $(0.2418)$ & $7.51 \%$ \\
\hline & & ISO 9001 implementation (0.1437) & $4.31 \%$ & & & Orders defect rate $(0.1973)$ & $6.13 \%$ \\
\hline & & Manufacturing capability $(0.2389)$ & $3.85 \%$ & & \multirow{7}{*}{$\begin{array}{c}\text { Capacity } \\
0.2188\end{array}$} & Manufacturing capability $(0.1623)$ & $3.55 \%$ \\
\hline & & Technological capability (0.1371) & $2.21 \%$ & & & Technological capability (0.0947) & $2.07 \%$ \\
\hline & Capacity & Flexibility in production $(0.2861)$ & $4.61 \%$ & & & Flexibility in production $(0.1898)$ & $4.15 \%$ \\
\hline & 0.1613 & Inventory turnover $(0.0970)$ & $1.56 \%$ & & & Employee availability (0.0809) & $1.77 \%$ \\
\hline & & Employee turnover (0.0672) & $1.08 \%$ & & & Time to Recovery (TTR) (0.1157) & $2.53 \%$ \\
\hline & & Capability enhancement $(0.1736)$ & $2.80 \%$ & & & Inventory turnover $(0.0999)$ & $2.18 \%$ \\
\hline & & Reliability of delivery service $(0.3245)$ & $4.55 \%$ & & & Shortages of raw materials $(0.2568)$ & $5.62 \%$ \\
\hline & Service & Sharing of information $(0.1325)$ & $1.86 \%$ & & \multirow{5}{*}{$\begin{array}{c}\text { Service } \\
0.1540\end{array}$} & Reliability of delivery service $(0.2579)$ & $3.97 \%$ \\
\hline & & Speed and timeliness of communication $(0.2845)$ & $3.99 \%$ & & & Sharing of Information $(0.1016)$ & $1.56 \%$ \\
\hline & & Warranty $(0.2586)$ & $3.62 \%$ & & & Speed and timeliness of communication $(0.2048)$ & $3.15 \%$ \\
\hline & \multirow{5}{*}{$\begin{array}{c}\text { Finance } \\
0.0629\end{array}$} & Fixed assets $(0.1545)$ & $0.97 \%$ & & & Accuracy of product and quantity delivered (0.3336) & $5.14 \%$ \\
\hline & & Comparative balance sheet $(0.1367)$ & $0.86 \%$ & & & Returns (0.1021) & $1.57 \%$ \\
\hline & & Debt or credit rating $(0.1671)$ & $1.05 \%$ & & \multirow{5}{*}{$\begin{array}{c}\text { Finance } \\
0.0599\end{array}$} & Fixed assets $(0.1345$ & $0.81 \%$ \\
\hline & & Financial capability $(0.2230)$ & $1.40 \%$ & & & Comparative balance sheet $(0.1406)$ & $0.84 \%$ \\
\hline & & Financial stability $(0.3186)$ & $2.01 \%$ & & & Debt or credit rating $(0.1636)$ & $0.98 \%$ \\
\hline & \multirow{5}{*}{$\begin{array}{c}\text { ICT } \\
0.0590\end{array}$} & $\mathrm{PO}$ and payment system $(0.1891)$ & $1.12 \%$ & & & Financial capability $(0.2386)$ & $1.43 \%$ \\
\hline & & Production and scheduling system $(0.3098)$ & $1.83 \%$ & & & Financial stability $(0.3226)$ & $1.93 \%$ \\
\hline & & Inventory management system $(0.1398)$ & $0.83 \%$ & & \multirow{3}{*}{$\begin{array}{c}\text { ICT } \\
0.0589\end{array}$} & PO and payment system $(0.2249)$ & $1.33 \%$ \\
\hline & & Barcode and RFID system (0.0991) & $0.59 \%$ & & & Production and scheduling system $(0.5055)$ & $2.98 \%$ \\
\hline & & Enterprise Resource Planning (ERP) (0.2622) & $1.55 \%$ & & & Inventory management system $(0.2696)$ & $1.59 \%$ \\
\hline & \multirow{7}{*}{$\begin{array}{c}\text { Sustainability } \\
0.0509\end{array}$} & Work safety and labor health $(0.3616)$ & $1.84 \%$ & & \multirow{7}{*}{$\begin{array}{c}\text { Sustainability } \\
0.0515\end{array}$} & Work safety and labor health (0.5707) & $2.94 \%$ \\
\hline & & Employment practices $(0.0996)$ & $0.51 \%$ & & & Employment practices $(0.2014)$ & $1.04 \%$ \\
\hline & & Product design for environment (Eco-design) (0.1339) & $0.68 \%$ & & & Contractual stakeholders influence $(0.2279)$ & $1.17 \%$ \\
\hline & & Environmental management system $(0.1153)$ & $0.59 \%$ & & & & \\
\hline & & Investment in R\&D (0.1347) & $0.69 \%$ & & & & \\
\hline & & ISO 14001 implementation (0.1549) & $0.79 \%$ & & & & \\
\hline & & & 1.0 & & & & 1.0 \\
\hline
\end{tabular}




\subsubsection{Results of AHP in the Supplier Selection Phase}

The analytical results of the main dimension criteria for supplier selection are shown in Table 4, with an inconsistency value of 0.02 and a high consensus (80.5\%). According to the ranking, the main dimensions were 'Quality,' ‘Cost,' 'Capacity,' 'Service,' 'Finance,' ‘ICT,' and 'Sustainability.' Additionally, priority weights and ranking of criteria are shown in Table 5.

Table 4. The priority weights and ranking of main dimensions for supplier selection.

\begin{tabular}{|c|c|c|c|c|c|c|c|c|c|}
\hline \multirow{2}{*}{ Dimension } & \multicolumn{7}{|c|}{ Pair-Wise Comparisons } & \multirow{2}{*}{$\begin{array}{l}\text { Importance } \\
\text { Weight }\end{array}$} & \multirow{2}{*}{ Ranking } \\
\hline & Cost & Quality & Capacity & Service & Finance & ICT & Sustainability & & \\
\hline Cost & 1 & 0.5807 & 1.5746 & 1.8626 & 3.2571 & 4.8666 & 4.1987 & 0.2259 & 2nd \\
\hline Quality & 1.7220 & 1 & 2.3686 & 2.3631 & 3.4193 & 5.0287 & 4.6544 & 0.2998 & 1st \\
\hline Capacity & 0.6351 & 0.4222 & 1 & 1.3907 & 2.5813 & 3.0428 & 3.7050 & 0.1613 & $3 \mathrm{rd}$ \\
\hline Service & 0.5369 & 0.4232 & 0.7190 & 1 & 1.6685 & 3.5463 & 3.6674 & 0.1401 & 4 th \\
\hline Finance & 0.3070 & 0.2925 & 0.3874 & 0.5993 & 1 & 0.7387 & 0.8139 & 0.0629 & 5 th \\
\hline ICT & 0.2055 & 0.1989 & 0.3286 & 0.2820 & 1.3538 & 1 & 1.5879 & 0.0590 & 6 th \\
\hline Sustainability & 0.2382 & 0.2148 & 0.2699 & 0.2727 & 1.2286 & 0.6298 & 1 & 0.0509 & 7 th \\
\hline
\end{tabular}

Table 5. The priority weights and ranking of criteria for supplier selection.

\begin{tabular}{|c|c|c|c|c|c|}
\hline Dimension & Criteria & $\begin{array}{l}\text { Relative } \\
\text { Weight }\end{array}$ & $\begin{array}{l}\text { Relative } \\
\text { Ranking }\end{array}$ & $\begin{array}{l}\text { Global } \\
\text { Weight }\end{array}$ & $\begin{array}{c}\text { Global } \\
\text { Ranking }\end{array}$ \\
\hline \multirow{3}{*}{ Cost } & Product cost & 0.5860 & 1 st & 0.1324 & $1 \mathrm{st}$ \\
\hline & Ordering cost & 0.1855 & $3 \mathrm{rd}$ & 0.0419 & 9th \\
\hline & Logistics cost & 0.2285 & 2nd & 0.0516 & 4 th \\
\hline \multirow{4}{*}{ Quality } & Quality level & 0.3739 & $1 \mathrm{st}$ & 0.1121 & 2nd \\
\hline & Investment in quality improvement & 0.1620 & 3rd & 0.0486 & 5 th \\
\hline & Certification \& quality assurance & 0.3204 & 2nd & 0.0961 & $3 \mathrm{rd}$ \\
\hline & ISO 9001 implementation & 0.1437 & 4 th & 0.0431 & 8th \\
\hline \multirow{6}{*}{ Capacity } & Manufacturing capability & 0.2389 & 2nd & 0.0385 & 11th \\
\hline & Technological capability & 0.1371 & 4 th & 0.0221 & 14th \\
\hline & Flexibility in production & 0.2861 & 1 st & 0.0461 & 6th \\
\hline & Inventory turnover & 0.0970 & 5 th & 0.0156 & 19 th \\
\hline & Employee turnover & 0.0672 & 6th & 0.0108 & 23rd \\
\hline & Capability enhancement & 0.1736 & 3 rd & 0.0280 & 13th \\
\hline \multirow{4}{*}{ Service } & Reliability of delivery service & 0.3245 & $1 \mathrm{st}$ & 0.0455 & 7 th \\
\hline & Sharing of information & 0.1325 & 4th & 0.0186 & 16th \\
\hline & Speed and timeliness of communication & 0.2845 & 2nd & 0.0399 & 10th \\
\hline & Warranty & 0.2586 & 3rd & 0.0362 & 12th \\
\hline \multirow{5}{*}{ Finance } & Fixed assets & 0.1545 & 5 th & 0.0097 & 25th \\
\hline & Comparative balance sheet & 0.1367 & 4th & 0.0086 & 26th \\
\hline & Debt or credit rating & 0.1671 & $3 \mathrm{rd}$ & 0.0105 & 24th \\
\hline & Financial capability & 0.2230 & 2nd & 0.0140 & $21 \mathrm{st}$ \\
\hline & Financial stability & 0.3186 & 1 st & 0.0201 & 15 th \\
\hline \multirow{5}{*}{ ICT } & PO and payment system & 0.1891 & $3 \mathrm{rd}$ & 0.0112 & 22nd \\
\hline & Production and scheduling system & 0.3098 & 1 st & 0.0183 & 18th \\
\hline & Inventory management system & 0.1398 & 4th & 0.0083 & 27th \\
\hline & Barcode and RFID system & 0.0991 & 5 th & 0.0059 & 32th \\
\hline & Enterprise Resource Planning (ERP) & 0.2622 & 2nd & 0.0155 & 20th \\
\hline \multirow{6}{*}{ Sustainability } & Work safety and labor health & 0.3616 & 1st & 0.0184 & 17th \\
\hline & Employment practices & 0.0996 & 6th & 0.0051 & 33th \\
\hline & Product design for environment (Eco-design) & 0.1339 & 4th & 0.0068 & 30th \\
\hline & Environmental management system & 0.1153 & 5 th & 0.0059 & 31th \\
\hline & Investment in R\&D & 0.1347 & $3 r d$ & 0.0069 & 29th \\
\hline & ISO 14001 implementation & 0.1549 & 2nd & 0.0079 & 28th \\
\hline
\end{tabular}

According to the results, the 'Quality' (0.2998) dimension held the first rank. Therefore, it can be concluded that 'Quality' stood out as the most critical dimension for selecting suppliers in the 
automotive industry. The criterion of 'Quality level' (0.3739) was the most important criterion by holding the highest rank. Before selecting appropriate suppliers, automobile manufacturers must trial and test the quality level of the component. The 'Certification \& Quality assurance' came next in the ranking order, followed by 'Investment in quality improvement.' Finally, ISO 9001 implementation was ranked last in the list of quality dimensions.

The 'Cost' (0.2259) dimension had the second place in the priority list. Purchasing department attempts to choose the best supplier by considering the price of components and services. Therefore, 'Product cost' (0.5860) was found to be the most important criterion. The next criterion was 'Logistics cost', because transportation costs play a significant role in the automotive industry. Finally, the criterion of 'Ordering cost' was ranked last on the list.

The 'Capacity' (0.1613) dimension held the third rank in the ranking list. 'Flexibility in production' was ranked first. To satisfy the manufacturer's requirement, buyers expect their suppliers to provide the capability to support the manufacturing department. The criteria of 'Manufacturing capability' and 'capability enhancement' came next as per the ranking list. Finally, the 'Employee turnover' criterion was ranked last on the list.

The 'Service' (0.1401) dimension ranked after 'Capacity'. 'Reliability of delivery service' was ranked first in order to ensure that the supplier is able to supply the component through the production process. 'Speed and timeliness of communication' came next by the ranking order, followed by 'Warranty.' 'Sharing of Information' was the last to appear on the list.

The 'Finance' (0.0629) dimension held the fifth place. 'Financial stability' criteria were placed on the top rank to verify the financial condition of the supplier before signing a contract. 'Financial capability' came next regarding priority. The next ranked criterion was 'Debt or credit rating,' followed by 'Comparative balance sheet.' Finally, the criterion of 'Fixed Assets' held the fifth place in the ranking list.

The 'Information and Communication Technology' (ICT) (0.0590) dimension held the sixth rank. 'Production and scheduling system' obtained the highest rank. The information sharing system between buyers and suppliers is essential in this industry. It integrates all suppliers and manufacturers for sharing the information and data, such as sequence, order quantity, delivery quantity, location of delivery, and delivery date and time. 'Enterprise Resource Planning (ERP)' came next in the ranking list, followed by 'PO and payment system' and 'Inventory turnover.' Lastly, 'Barcode and RFID system' completed the ranking sequence.

Finally, the 'Sustainability (0.0509)' dimension was found to hold the lowest rank. Although it appears that manufacturers pay less attention to sustainability, they still examine the procedure and operation of their supplier should be safe on the regulation. 'Work safety and labor health' was the most important criterion, followed by 'ISO 14001 implementation'. 'Investment in R\&D' came next regarding priority. Finally, 'Employment practices' was ranked last in the list.

\subsubsection{Results of AHP in the Monitoring Phase}

From Table 6, the ranking of the main dimensions for monitoring includes 'Quality,' 'Capacity,' 'Service,' 'Cost,' 'Finance, 'ICT,' and 'Sustainability.' The consistency ratio was acceptable (0.007) and the AHP group consensus was high (86.9\%). We also determined the priority weights and ranking of criteria for the supplier monitoring phase (see Table 7). 
Table 6. The priority weights and ranking of main dimensions for supplier monitoring.

\begin{tabular}{|c|c|c|c|c|c|c|c|c|c|}
\hline \multirow{2}{*}{ Dimension } & \multicolumn{7}{|c|}{ Pair-Wise Comparisons } & \multirow{2}{*}{$\begin{array}{c}\text { Importance } \\
\text { Weight }\end{array}$} & \multirow{2}{*}{ Ranking } \\
\hline & Cost & Quality & Capacity & Service & Finance & ICT & Sustainability & & \\
\hline Cost & 1 & 0.4679 & 0.5219 & 0.8799 & 2.6008 & 3.0658 & 3.0008 & 0.1463 & 4th \\
\hline Quality & 2.1372 & 1 & 1.6545 & 2.6311 & 4.1060 & 5.2533 & 4.7940 & 0.3107 & 1st \\
\hline Capacity & 1.9162 & 0.6044 & 1 & 1.4792 & 3.3314 & 3.7612 & 4.0423 & 0.2188 & 2 nd \\
\hline Service & 1.1365 & 0.3801 & 0.6761 & 1 & 2.8949 & 2.4178 & 3.5856 & 0.1540 & 3rd \\
\hline Finance & 0.3845 & 0.2435 & 0.3002 & 0.3454 & 1 & 0.9245 & 1.1186 & 0.0599 & 5 th \\
\hline ICT & 0.3262 & 0.1904 & 0.2659 & 0.4136 & 1.0816 & 1 & 1.2329 & 0.0589 & 6th \\
\hline Sustainability & 0.3332 & 0.2086 & 0.2474 & 0.2789 & 0.8940 & 0.8111 & 1 & 0.0515 & 7 th \\
\hline
\end{tabular}

Table 7. The priority weights and ranking of criteria for supplier monitoring.

\begin{tabular}{|c|c|c|c|c|c|}
\hline Dimension & Criteria & $\begin{array}{l}\text { Relative } \\
\text { Weight }\end{array}$ & $\begin{array}{l}\text { Relative } \\
\text { Ranking }\end{array}$ & $\begin{array}{l}\text { Global } \\
\text { Weight }\end{array}$ & $\begin{array}{l}\text { Global } \\
\text { Ranking }\end{array}$ \\
\hline \multirow{3}{*}{ Cost } & Product cost & 0.4560 & 1st & 0.0667 & 4 th \\
\hline & Ordering cost & 0.1846 & 3 rd & 0.0270 & 15th \\
\hline & Logistics cost & 0.3594 & 2 nd & 0.0526 & 7 th \\
\hline \multirow{4}{*}{ Quality } & Quality level & 0.3145 & $1 \mathrm{st}$ & 0.0977 & $1 \mathrm{st}$ \\
\hline & Responsibility for product quality & 0.2464 & 2nd & 0.0766 & 2nd \\
\hline & Responsiveness for product quality & 0.2418 & $3 \mathrm{rd}$ & 0.0751 & $3 \mathrm{rd}$ \\
\hline & Orders defect rate & 0.1973 & 4 th & 0.0613 & 5 th \\
\hline \multirow{7}{*}{ Capacity } & Manufacturing capability & 0.1623 & $3 r d$ & 0.0355 & 11th \\
\hline & Technological capability & 0.0947 & 6 th & 0.0207 & 18th \\
\hline & Flexibility in production & 0.1898 & 2nd & 0.0415 & 9th \\
\hline & Employee availability & 0.0809 & 7 th & 0.0177 & 20th \\
\hline & Time to Recovery (TTR) & 0.1157 & 4th & 0.0253 & 16th \\
\hline & Inventory turnover & 0.0999 & 5 th & 0.0218 & 17th \\
\hline & Shortages of raw materials & 0.2568 & $1 \mathrm{st}$ & 0.0562 & 6th \\
\hline \multirow{5}{*}{ Service } & Reliability of delivery service & 0.2579 & 2nd & 0.0397 & 10th \\
\hline & Sharing of Information & 0.1016 & 5 th & 0.0156 & 23rd \\
\hline & Speed and timeliness of communication & 0.2048 & 3 rd & 0.0315 & 12 th \\
\hline & Accuracy of product and quantity delivered & 0.3336 & 1 st & 0.0514 & 8th \\
\hline & Returns & 0.1021 & 4th & 0.0157 & 22nd \\
\hline \multirow{5}{*}{ Finance } & Fixed assets & 0.1345 & 5 th & 0.0081 & 30th \\
\hline & Comparative balance sheet & 0.1406 & 4 th & 0.0084 & 29th \\
\hline & Debt or credit rating & 0.1636 & $3 \mathrm{rd}$ & 0.0098 & 28th \\
\hline & Financial capability & 0.2386 & 2nd & 0.0143 & 24th \\
\hline & Financial stability & 0.3226 & 1 st & 0.0193 & 19th \\
\hline \multirow{3}{*}{ ICT } & PO and payment system & 0.2249 & $3 r d$ & 0.0133 & 25 th \\
\hline & Production and scheduling system & 0.5055 & 1 st & 0.0298 & 13 th \\
\hline & Inventory management system & 0.2696 & 2nd & 0.0159 & $21 \mathrm{st}$ \\
\hline \multirow{3}{*}{ Sustainability } & Work safety and labor health & 0.5707 & 1 st & 0.0294 & 14th \\
\hline & Employment practices & 0.2014 & $3 \mathrm{rd}$ & 0.0104 & 27th \\
\hline & Contractual stakeholders influence & 0.2279 & 2nd & 0.0117 & 26th \\
\hline
\end{tabular}

The 'Quality' (0.3107) dimension ranked the first as the most important dimension for monitoring suppliers. To avoid defective components, 'Quality level' was found to be the most important criterion in order to achieve a sustainable relationship in the long term. 'Responsibility for product quality' came next in the ranking order, followed by 'Responsiveness for product quality.' Finally, 'Orders Defect rate' was ranked last in the list.

The 'Capacity' (0.2188) dimension held the second rank in the list. The criterion of 'Shortages of raw materials' was found to be the most important criterion to ensure a consistent supply. The capacity of the suppliers is tracked by the manufacturing department to prevent production disruption. The 'Flexibility in production' appeared next as per the ranking list, followed by 'Manufacturing capability,' and 'Time to recovery.' The next place was attained by 'Inventory turnover.' 'Employee availability' was ranked last on the list. 
The priority ranking of the 'Service' dimension (0.1540) was third in the ranking. Service quality of suppliers is important to evaluate during the production process by the manufacturing department. 'Accuracy of product and quantity delivered' turned out to be the most important. 'Reliability of delivery service' came next regarding priority. Finally, 'Sharing of Information' appeared last in the list.

The 'Cost' (0.1463) dimension held fourth place in the priority list. 'Product cost' obtained the highest rank. The purchasing department verifies that the cost is still stable or changing because of 'Product cost', which has an impact on profit. Likewise, the next ranked criterion was 'Logistics cost,' followed by 'Ordering cost', which was ranked last in the list.

'Finance' (0.0599) held the fifth rank. 'Financial stability', which is a critical factor for monitoring suppliers, obtained the highest rank. It is clear that the 'Finance' dimension should not only be concerned with selecting suppliers. 'Financial stability' obtained the highest rank. The next criterion was 'Financial capability.' Finally, the criterion of 'Fixed Assets' held fifth place in the ranking list.

The 'ICT' dimension (0.0589) held the sixth rank. ICT is used for tracking the continuous operation of suppliers. The results showed that 'Production and scheduling system' turned out to be the most important criterion. 'Inventory management system' came next in the ranking list. Finally, 'PO and payment system' was ranked last in the list.

Among the main dimensions, the 'Sustainability' dimension (0.0515) had the lowest priority. The criterion of 'Work safety and labor health' was found to be the most important criterion for auditing the workplace of suppliers. The 'contractual stakeholder's influence' appeared next as per the ranking list. Finally, the 'Employment practice' criterion completed the ranking sequence.

\subsection{Compare and Analyze Different Criteria}

\subsubsection{Pareto Analysis}

Pareto analysis was used to prioritize the important criteria for selecting suppliers (see Figure 3). The results show that 33 criteria of supplier selection were reduced to 15 criteria, including the criteria in the following dimensions: 'Cost,' 'Quality,' 'Capacity,' 'Service,' and 'Finance' (see Table 8). In particular, 'Product cost' obtained the top priority for selecting suppliers, followed by 'Quality level,' 'Certificate \& quality assurance,' 'Logistics cost,' and 'Investment in quality improvement', which were identified as the top five criteria for supplier selection. However, the criteria under 'ICT' and 'Sustainability' dimensions were not defined as important in the supplier selection phase.

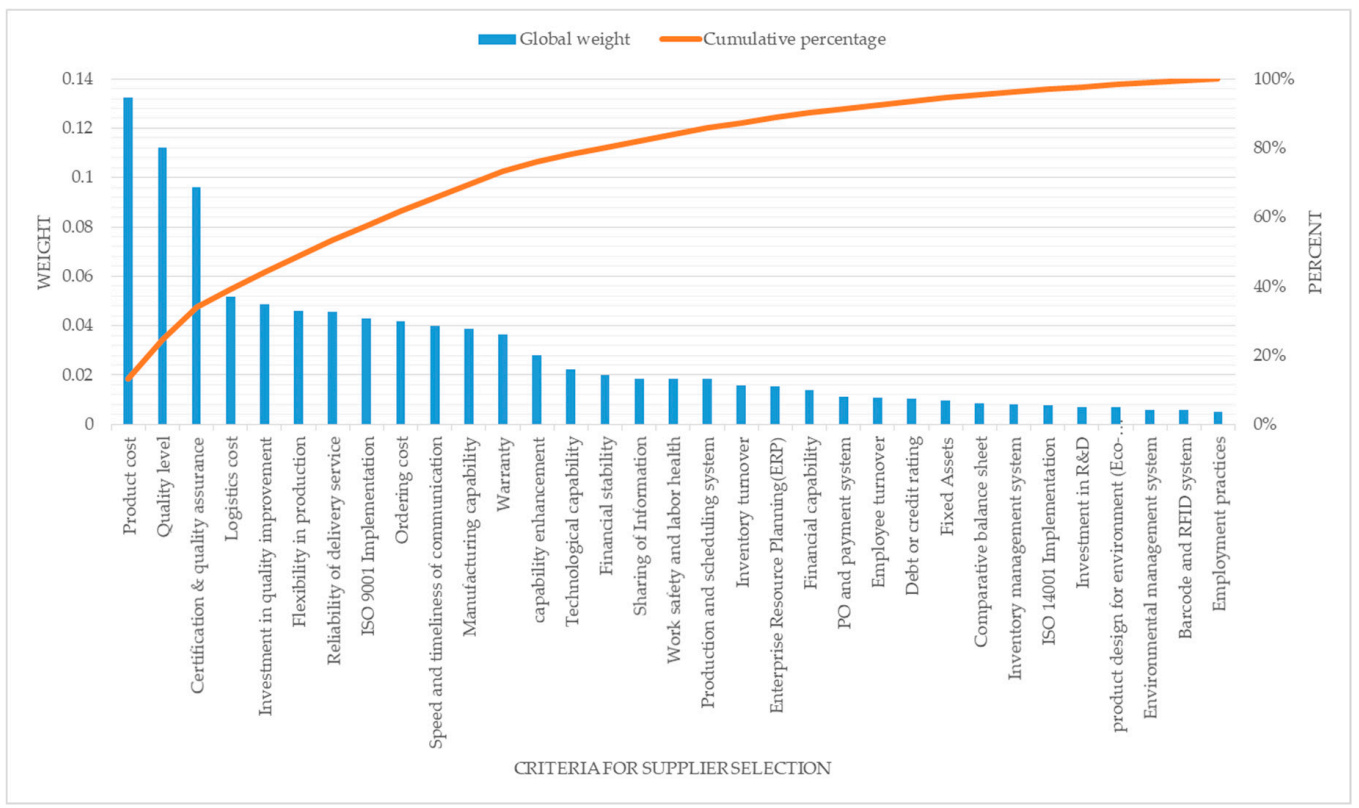

Figure 3. A Pareto chart to select important criteria for supplier selection. 
Table 8. Important criteria for supplier selection.

\begin{tabular}{|c|c|c|c|c|}
\hline Dimension & Important Criteria & $\begin{array}{c}\text { Selection Global } \\
\text { Weight }\end{array}$ & $\begin{array}{l}\text { Selection Global } \\
\text { Ranking }\end{array}$ & Cumulative \% \\
\hline Cost & Product cost & 0.1324 & 1st & $13.24 \%$ \\
\hline Quality & Quality level & 0.1121 & 2nd & $24.45 \%$ \\
\hline Quality & Certification \& quality assurance & 0.0961 & $3 r d$ & $34.05 \%$ \\
\hline Cost & Logistics cost & 0.0516 & 4th & $39.22 \%$ \\
\hline Quality & Investment in quality improvement & 0.0486 & 5 th & $44.07 \%$ \\
\hline Capacity & Flexibility in production & 0.0461 & 6th & $48.69 \%$ \\
\hline Service & Reliability of delivery service & 0.0455 & 7th & $53.23 \%$ \\
\hline Quality & ISO 9001 implementation & 0.0431 & 8th & $57.54 \%$ \\
\hline Cost & Ordering cost & 0.0419 & 9th & $61.73 \%$ \\
\hline Service & Speed and timeliness of communication & 0.0399 & 10th & $65.72 \%$ \\
\hline Capacity & Manufacturing capability & 0.0385 & 11th & $69.57 \%$ \\
\hline Service & Warranty & 0.0362 & 12th & $73.20 \%$ \\
\hline Capacity & Capability enhancement & 0.0280 & 13th & $76.00 \%$ \\
\hline Capacity & Technological capability & 0.0221 & 14th & $78.21 \%$ \\
\hline Finance & Financial stability & 0.0201 & 15th & $80.21 \%$ \\
\hline
\end{tabular}

Important criteria in the supplier monitoring phase are shown in Figure 4. From 30 criteria, 16 were selected, included the criteria in the following dimensions: 'Quality,' 'Cost,' 'Capacity,' 'Service,' 'ICT,' and 'Sustainability'. The results in Table 9 show that all criteria under 'Quality' and 'Cost' dimensions were included in the set of important criteria for monitoring suppliers. More specifically, the 'Quality level' ranked as the top priority for monitoring suppliers. 'Responsibility for product quality,' 'Responsiveness for product quality,' 'Product cost,' and 'Orders Defect rate' were the top five of the important criteria for supplier monitoring. However, only the criterions in the 'Finance' dimension were determined in the set of important criteria for monitoring suppliers.

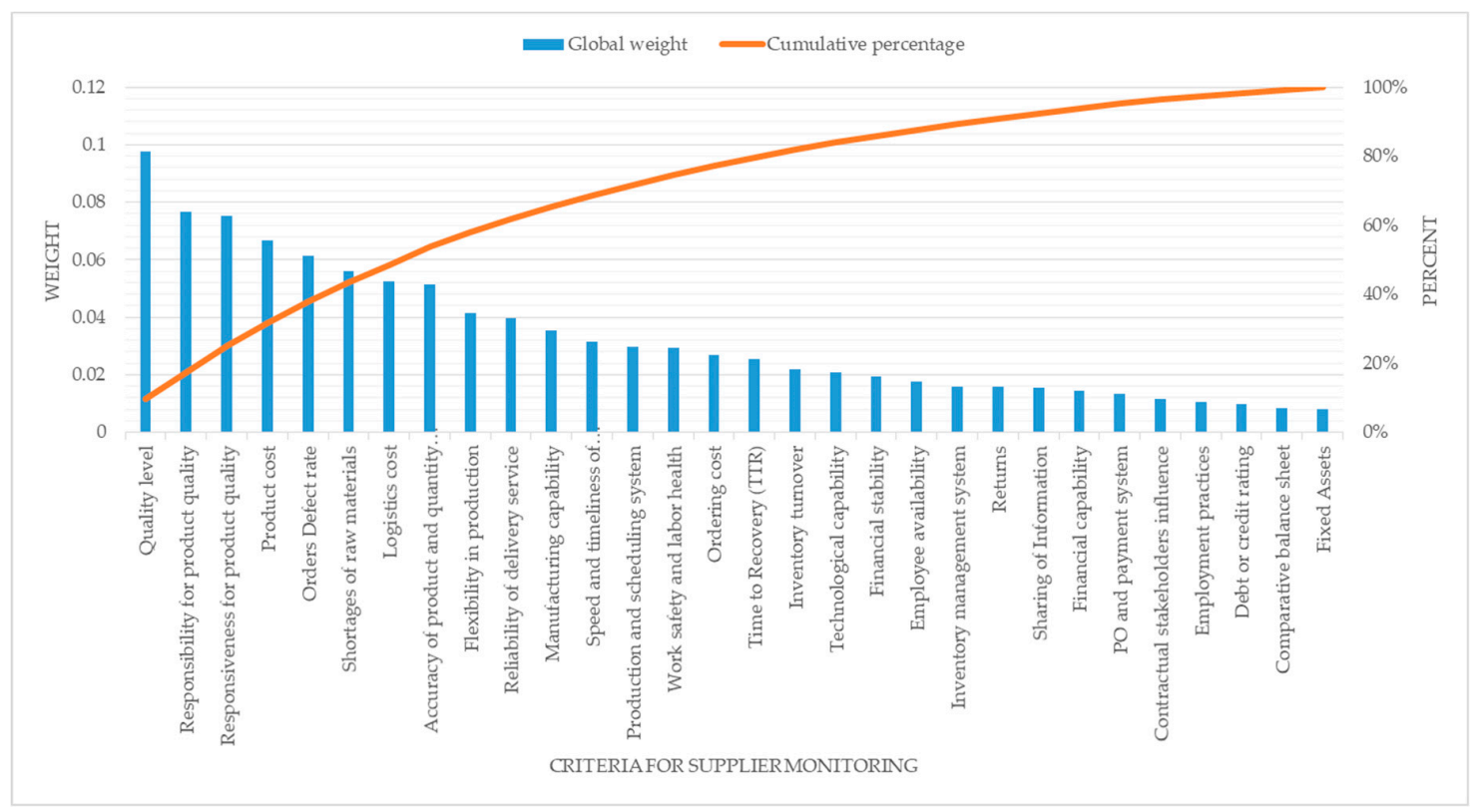

Figure 4. A Pareto chart to select important criteria for supplier monitoring. 
Table 9. Important criteria for supplier monitoring.

\begin{tabular}{llccc}
\hline Dimension & \multicolumn{1}{c}{ Important Criteria } & $\begin{array}{c}\text { Monitoring } \\
\text { Global Weight }\end{array}$ & $\begin{array}{c}\text { Monitoring } \\
\text { Global Ranking }\end{array}$ & Cumulative \% \\
\hline Quality & Quality level & 0.0977 & 1 st & $9.77 \%$ \\
Quality & Responsibility for product quality & 0.0766 & 2nd & $17.43 \%$ \\
Quality & Responsiveness for product quality & 0.0751 & $3 \mathrm{rd}$ & $24.94 \%$ \\
Cost & Product cost & 0.0667 & 4 th & $31.61 \%$ \\
Quality & Orders defect rate & 0.0613 & 5 th & $37.74 \%$ \\
Capacity & Shortages of raw materials & 0.0562 & 6 th & $43.36 \%$ \\
Cost & Logistics cost & 0.0526 & 7 th & $48.61 \%$ \\
Service & Accuracy of product and quantity delivered & 0.0514 & 8 th & $53.75 \%$ \\
Capacity & Flexibility in production & 0.0415 & 9 th & $57.90 \%$ \\
Service & Reliability of delivery service & 0.0397 & 10 th & $61.87 \%$ \\
Capacity & Manufacturing capability & 0.0355 & 11 th & $65.42 \%$ \\
Service & Speed and timeliness of communication & 0.0315 & 12 th & $68.57 \%$ \\
ICT & Production and scheduling system & 0.0298 & 13 th & $71.55 \%$ \\
Sustainability & Work safety and labor health & 0.0294 & 14 th & $74.49 \%$ \\
Cost & Ordering cost & 0.0270 & 15 th & $77.19 \%$ \\
Capacity & Time to Recovery (TTR) & 0.0253 & 16 th & $79.72 \%$ \\
\hline
\end{tabular}

\subsubsection{Comparison of criteria}

From the analytical results shown in Table 10, the 'Quality' dimension stood out as a highly important criterion for both the supplier selection and the monitoring phases. Inspection of the vehicle is essential to control quality in the automotive industry. The manufacturing department expects their suppliers to supply quality components. Meanwhile, the purchasing department selects suppliers who provide a reasonable price to maintain a competitive advantage. As a result, the priority ranking of the 'Cost' dimension in the supplier selection phase held the second rank, but it appeared to have a lower priority in the monitoring phase. Moreover, the results show that the 'Capacity' and 'Service' dimensions obtained a higher priority for maintaining the production process in the monitoring phase. Besides, the priority ranking of the 'Finance,' 'ICT,' and 'Sustainability' dimensions held the same rank in the priority list in the selection and monitoring phase.

Table 10. Comparison and ranking of dimensions in supplier selection and monitoring.

\begin{tabular}{ccccc}
\hline Dimension & Selection Weight & Monitoring Weight & Selection Rank & Monitoring Rank \\
\hline Cost & 0.2259 & 0.1463 & $2 \mathrm{nd}$ & 4 th \\
Quality & 0.2998 & 0.3107 & $1 \mathrm{st}$ & 1st \\
Capacity & 0.1613 & 0.2188 & $3 \mathrm{rd}$ & 2nd \\
Service & 0.1401 & 0.1540 & 4 th & 3rd \\
Finance & 0.0629 & 0.0599 & 5 th & 5 th \\
ICT & 0.0590 & 0.0589 & 6 th & 6th \\
Sustainability & 0.0509 & 0.0515 & th & 7 th \\
\hline
\end{tabular}

The factors for supplier selection and monitoring have a multiple-criteria character. The differences in the criteria between the supplier selection and the supplier monitoring phases are summarized in Table 11. The 'Product cost' was found to be the top criterion for supplier selection. Furthermore, 'Logistics cost,' and 'Ordering cost' were identified to be among the top ten criteria in the supplier selection phase. However, these three criteria had a lower priority in the monitoring phase compared to the selection phase. It is possible that the criterion under 'Cost' dimension was calculated and decided in the selecting phase. Moreover, the manufacturing department pays more attention to other dimensions, such as 'Quality,' 'Capacity,' and 'Service, which can directly affect manufacturing processes. 
Table 11. Comparison and ranking of criteria in supplier selection and monitoring.

\begin{tabular}{|c|c|c|c|c|c|c|c|}
\hline \multirow{2}{*}{ Dimension } & \multirow{2}{*}{ Criteria } & \multirow{2}{*}{ Selection } & \multirow{2}{*}{ Monitoring } & \multicolumn{2}{|c|}{ Selection } & \multicolumn{2}{|c|}{ Monitoring } \\
\hline & & & & Weight & Rank & Weight & Rank \\
\hline \multirow{3}{*}{ Cost } & Product cost & $\checkmark$ & $\checkmark$ & 0.1324 & 1st & 0.0667 & 4th \\
\hline & Ordering cost & $\boldsymbol{\nu}$ & $\checkmark$ & 0.0516 & 4th & 0.0526 & 7th \\
\hline & Logistics cost & $\checkmark$ & $\checkmark$ & 0.0419 & 9th & 0.0270 & 15th \\
\hline \multirow{7}{*}{ Quality } & Quality level & $\boldsymbol{v}$ & $\boldsymbol{v}$ & 0.1121 & 2nd & 0.0977 & $1 \mathrm{st}$ \\
\hline & Investment in quality improvement & $\boldsymbol{v}$ & - & 0.0961 & $3 \mathrm{rd}$ & - & - \\
\hline & Certification \& quality assurance & $\boldsymbol{\nu}$ & - & 0.0486 & 5 th & - & - \\
\hline & ISO 9001 implementation & $\boldsymbol{\nu}$ & - & 0.0431 & 8th & - & - \\
\hline & Responsibility for product quality & - & $\boldsymbol{\nu}$ & - & - & 0.0766 & 2nd \\
\hline & Responsiveness for product quality & - & $\checkmark$ & - & - & 0.0751 & $3 \mathrm{rd}$ \\
\hline & Orders defect rate & - & $\checkmark$ & - & - & 0.0613 & 5 th \\
\hline \multirow{6}{*}{ Capacity } & Flexibility in production & $\checkmark$ & $\boldsymbol{v}$ & 0.0461 & 6th & 0.0415 & 9th \\
\hline & Manufacturing capability & $\checkmark$ & $\checkmark$ & 0.0385 & 11 th & 0.0355 & 11 th \\
\hline & Capability enhancement & $\checkmark$ & - & 0.0280 & 13th & - & - \\
\hline & Technological capability & $\boldsymbol{v}$ & - & 0.0221 & 14th & - & - \\
\hline & Shortages of raw materials & - & $\checkmark$ & - & - & 0.0562 & 6th \\
\hline & Time to Recovery (TTR) & - & $\checkmark$ & - & - & 0.0253 & 16 th \\
\hline \multirow{4}{*}{ Service } & Reliability of delivery service & $\checkmark$ & $\boldsymbol{v}$ & 0.0455 & 7th & 0.0397 & 10th \\
\hline & $\begin{array}{l}\text { Speed and timeliness of } \\
\text { communication }\end{array}$ & $\checkmark$ & $\checkmark$ & 0.0399 & 10th & 0.0315 & 12 th \\
\hline & Warranty & $\checkmark$ & - & 0.0362 & 12th & - & - \\
\hline & $\begin{array}{l}\text { Accuracy of product and quantity } \\
\text { delivered }\end{array}$ & - & $\boldsymbol{V}$ & 0.0002 & - & 0.0514 & 8 th \\
\hline Finance & Financial stability & $\checkmark$ & - & 0.0201 & 15th & - & - \\
\hline ICT & Production and scheduling system & - & $\checkmark$ & - & - & 0.0298 & 13th \\
\hline Sustainability & Work safety and labor health & - & $\boldsymbol{v}$ & - & - & 0.0294 & 14th \\
\hline
\end{tabular}

Based on the results, all criteria under the 'Quality' dimension were included in the set of important criteria for both the supplier selection and the monitoring phases. Although the 'Quality' dimension was found to be the most important criterion for both the supplier selection and the monitoring phases, priority weight of 'Quality level' was ranked second, after 'Product cost,' in the selection phase. 'Quality level' was found to be the top criterion in the monitoring phase. There were differences in the criteria in the 'Quality' dimension. Specifically, 'Certification \& assurance' and 'Investment in quality improvement' were among the top five criteria for supplier selection. Nevertheless, 'Responsibility for product quality,' 'Responsiveness for product quality,' and 'Defect rate' were ranked as three of the top five criteria for monitoring suppliers in the supply chain. These results demonstrate that quality stands out as the most significant goal in the automotive industry.

In addition, 'Capacity' and 'Service' were found to be key objectives to maintain the manufacturing process as efficiently as possible. The manufacturing department requires their suppliers to support a continuous production system. 'Flexibility in production' in the 'Capacity' dimension was identified as the most important criterion for selecting an appropriate supplier, whereas 'Shortages of raw materials' was the most important criterion for monitoring suppliers. 'Reliability of delivery service' in the 'Service' dimension was found to be the most important criterion to select a supplier. However, the results show that 'Accuracy of product and quantity delivered' was a highly important criterion in the monitoring phase.

Based on the results, it can be concluded that there is a difference between selecting and monitoring suppliers in terms of the set of criteria and their relative weights. Additionally, there is a conflict between the purchasing and manufacturing departments based on the 'Cost' and 'Quality' dimension. The ultimate goal of a purchasing department is to reduce costs. On the other hand, the goal of the manufacturing department is to obtain quality products from their suppliers through the production process. Although the purchasing department selects the best supplier according to all manufacturing requirements, it may lead to other problems, such as high production costs and a decrease in profit. 
Therefore, in order to develop sustainable supplier management in the automotive industry, purchasing and manufacturing departments should collaborate on selecting and monitoring suppliers. Beyond the criteria in the 'Cost' dimension, purchasing managers should assign more weight to other criteria. Manufacturing managers should also focus more on the capacity and service of the supplier, not only on the 'Quality' dimension. Finally, relative weights of the criteria should be continuously updated.

\section{Conclusions}

Purchasing is the one of the most important functions to determine strategic operations of effective supply chain management. With the integration of the global market, the critical role of the outsourcing strategy for efficient supply chain management has been widely recognized. Due to the current business environment, many factors can affect the supplier's ability. Organizations should not only select the right supplier, but also continuously monitor their supplier. Therefore, supplier selection is one of the most challenging decisions in the purchasing process. In addition, supplier monitoring has been identified as an essential consideration for organizations in order to ensure the overall supply chain performance. However, it is very hard to find previous research which takes account of the differences of critical factors between supplier selection and the monitoring process. In this study, a novel framework has been designed to integrate the supplier selection and monitoring phase.

The results of comparing the priority rankings using AHP provide comprehensive insights into the supplier selection and supplier monitoring criteria. These results highlight that there is a difference in the relative importance of the criteria between supplier selection and supplier monitoring. The results also show that 'Quality' stands out as the most important dimension in both the supplier selection and the monitoring phases. Furthermore, the 'Cost' dimension holds a lower rank in supplier monitoring. The priority ranking of 'Capacity' and 'Service' is higher in supplier monitoring. Furthermore, we also identified sets of criteria within their main dimensions and ranked them in terms of their importance. 'Product cost' ranked as the top criterion for supplier selection, whereas it was found to have a lower priority in the monitoring phase. 'Quality level' ranked after 'Product cost' in the selection phase, but received the highest rank for monitoring suppliers.

The ultimate goals of both purchasing and production departments are different and sometimes mutually contradictory. Therefore, it cannot be argued that the basic common strategy for both departments is reducing the costs. However, purchasing has a higher priority for finding suppliers with a lower price, while quality is emphasized more for the production. While the goal of manufacturing is to receive quality components, both departments should collaborate on selecting and monitoring their suppliers. Therefore, it can be argued that a company should integrate the supplier selection and the monitoring processes by updating the relative weights of the important criteria between the two phases. In addition, managers should develop a cooperative program between the purchasing and manufacturing departments. This may help each department to better understand the interrelated processes for supplier relationship management.

In the present study, we proposed a novel framework to explore, compare, and analyze the criteria for supplier selection and monitoring. As the automobile industry has been regarded as a key driving factor of economic growth in Thailand, the insights obtained in the present study regarding the factors for supplier selection and monitoring can increase the efficiency of purchasing. Meanwhile, managers should also understand and recognize the difference of criteria while selecting and monitoring suppliers for their organization.

Still, some limitations exist. First, because the proposed framework has been applied to the auto industry, it is hard to generalize the results of comparative analysis, such as rank and relative weights of critical factors. Therefore, to generalize our findings, the proposed framework should be extended to other industries. In addition, every company has its own processes and policies to select and monitor suppliers. This study has focused on differences of the criteria to select and monitor suppliers. The proposed framework can be improved by suggesting ways to integrate it with the current system 
and process. It may be helpful to design an intelligent system to automatically synchronize relative weights of important factors as a cycle between the supplier selection and monitoring phases.

Author Contributions: Conceptualization, J.S.; Methodology, J.S.; Software, J.S.; Validation, J.S. and K.S.; Formal Analysis, J.S.; Investigation, J.S.; Resources, J.S.; Data Curation, J.S.; Writing-Original Draft Preparation, J.S.; Writing-Review \& Editing, K.S.; Visualization, J.S.; Supervision, K.S.

Funding: This research received no external funding.

Acknowledgments: The authors do appreciate for every expert in automotive industry who replied to the survey. The experts helped authors to find key factors to manage relationship with suppliers.

Conflicts of Interest: The authors declare no conflict of interest.

\section{References}

1. Omurca, S.I. An intelligent supplier evaluation, selection and development system. Appl. Soft Comput. J. 2013, 13, 690-697. [CrossRef]

2. Lima-Junior, F.R.; Carpinetti, L.C.R. Combining SCOR ${ }^{\circledR}$ model and fuzzy TOPSIS for supplier evaluation and management. Int. J. Prod. Econ. 2016, 174, 128-141. [CrossRef]

3. Lee, D.M.; Drake, P.R. A portfolio model for component purchasing strategy and the case study of two South Korean elevator manufacturers. Int. J. Prod. Res. 2010, 48, 6651-6682. [CrossRef]

4. Ericksen, P. A Look at Purchasing Strategies Part 1: Piece-Price. Available online: https://www.maketime. io/blog/purchasing-strategies-piece-price/ (accessed on 10 December 2018).

5. Talluri, S.; Sarkis, J. A model for performance monitoring of suppliers. Int. J. Prod. Res. 2002, 40, 4257-4269. [CrossRef]

6. Wu, D. Supplier selection: A hybrid model using DEA, decision tree and neural network. Expert Syst. Appl. 2009, 36, 9105-9112. [CrossRef]

7. Torabi, S.A.; Baghersad, M.; Mansouri, S.A. Resilient supplier selection and order allocation under operational and disruption risks. Transp. Res. Part E 2015, 79, 22-48. [CrossRef]

8. Vahidi, F.; Torabi, S.A.; Ramezankhani, M.J. Sustainable supplier selection and order allocation under operational and disruption risks. J. Clean. Prod. 2018, 174, 1351-1365. [CrossRef]

9. Luthra, S.; Govindan, K.; Kannan, D.; Mangla, S.K.; Garg, C.P. An integrated framework for sustainable supplier selection and evaluation in supply chains. J. Clean. Prod. 2017, 140, 1686-1698. [CrossRef]

10. Zimmer, K.; Fröhling, M.; Schultmann, F. Sustainable supplier management-A review of models supporting sustainable supplier selection, monitoring and development. Int. J. Prod. Res. 2016, 54, 1412-1442. [CrossRef]

11. Deng, X.; Hu, Y.; Deng, Y.; Mahadevan, S. Supplier selection using AHP methodology extended by D numbers. Expert Syst. Appl. 2014, 41, 156-167. [CrossRef]

12. Dey, P.K.; Bhattacharya, A.; Ho, W. Strategic supplier performance evaluation: A case-based action research of a UK manufacturing organisation. Int. J. Prod. Econ. 2015, 166, 192-214. [CrossRef]

13. Thailand Board of Investment. Automotive Industry; Thailand Board of Investment: Bangkok, Thailand, 2017.

14. Das, K. Industry Spotlight: Thailand's Automotive Industry. Available online: https://www.aseanbriefing. com/news/2017/03/17/thailand-automotive-industry.html (accessed on 5 December 2018).

15. Hananto, A. Thailand's Automotive Industry. The Biggest Auto Hub in Southeast Asia. 2017. Available online: https:/ / seasia.co/2017/03/19/thailand-s-automotive-industry-the-biggest-auto-hub-in-southeastasia (accessed on 18 December 2018).

16. Rastogi, V. Thailand's Automotive Industry: Opportunities and Incentives. Available online: https://www. aseanbriefing.com/news/2018/05/10/thailands-automotive-industry-opportunities-incentives.html (accessed on 9 December 2018).

17. Shaw, K.; Shankar, R.; Yadav, S.S.; Thakur, L.S. Supplier selection using fuzzy AHP and fuzzy multi-objective linear programming for developing low carbon supply chain. Expert Syst. Appl. 2012, 39, 8182-8192. [CrossRef]

18. Akman, G.; Pjgkjn, H. Evaluating green performance of suppliers via analytic network process and TOPSIS. J. Ind. Eng. 2013, 2013, 1-13. [CrossRef]

19. Lee, T.R.; Le, T.P.N.; Genovese, A.; Koh, L.S.C. Using FAHP to determine the criteria for partner's selection within a green supply chain: The case of hand tool industry in Taiwan. J. Manuf. Technol. Manag. 2011, 23, 25-55. [CrossRef] 
20. Sagar, M.; Singh, D. Supplier selection criteria: Study of automobile sector in India. Int. J. Eng. Res. Dev. 2012, 4, 34-39.

21. Muraldiharan, C.; Anantharaman, N.; Deshmukh, S.G. A multi-criteria group decisionmaking model for supplier rating. J. Supply Chain Manag. 2002, 38, 22-35. [CrossRef]

22. Hou, J.; Su, D. EJB-MVC oriented supplier selection system for mass customization. J. Manuf. Technol. Manag. 2007, 18, 54-71. [CrossRef]

23. Dweiri, F.; Kumar, S.; Khan, S.A.; Jain, V. Designing an integrated AHP based decision support system for supplier selection in automotive industry. Expert Syst. Appl. 2016, 62, 273-283. [CrossRef]

24. Shen, L.; Muduli, K.; Barve, A. Developing a sustainable development framework in the context of mining industries: AHP approach. Resour. Policy 2015, 46, 15-26. [CrossRef]

25. Zhang, Q.; Shah, N.; Wassick, J.; Helling, R.; Van Egerschot, P. Sustainable supply chain optimisation: An industrial case study. Comput. Ind. Eng. 2014, 74, 68-83. [CrossRef]

26. Dey, P.K.; Cheffi, W. Green supply chain performance measurement using the analytic hierarchy process: A comparative analysis of manufacturing organisations. Prod. Plan. Control 2013, 24, 702-720. [CrossRef]

27. Yakovleva, N.; Sarkis, J.; Sloan, T. Sustainable benchmarking of supply chains: The case of the food industry. Int. J. Prod. Res. 2012, 50, 1297-1317. [CrossRef]

28. APICS. Supply Chain Council. Scor Supply Chain Operations Reference Model Ver. 11.0 Quick Reference Quide; APICS SCC Organization: Chicago, IL, USA, 2015; pp. 1-10.

29. Palma-Mendoza, J.A. Analytical hierarchy process and SCOR model to support supply chain re-design. Int. J. Inf. Manag. 2014, 34, 634-638. [CrossRef]

30. Gotzamani, K.D.; Tsiotras, G.D.; Nicolaou, M.; Nicolaides, A.; Hadjiadamou, V. The contribution to excellence of ISO 9001: The case of certified organisations in Cyprus. TQM Mag. 2007, 19, 388-402. [CrossRef]

31. Almeida, D.; Pradhan, N.; Muniz, J., Jr. Assessment of ISO 9001: 2015 implementation factors based on AHP. Int. J. Qual. Reliab. Manag. 2018, 35, 1343-1359. [CrossRef]

32. International Organization for Standardization. ISO 9001:2015. Available online: https://www.iso.org/ standard/62085.html (accessed on 9 December 2018).

33. Habidin, N.F.; Hibadullah, S.N.; Mohd Fuzi, N.; Salleh, M.I.; Md Latip, N.A. Lean manufacturing practices, ISO 14001, and environmental performance in Malaysian automotive suppliers. Int. J. Manag. Sci. Eng. Manag. 2018, 13, 45-53. [CrossRef]

34. Campos, L.M.S.; De Melo Heizen, D.A.; Verdinelli, M.A.; Cauchick Miguel, P.A. environmental performance indicators: a study on ISO 14001 certified companies. J. Clean. Prod. 2015, 99, 286-296. [CrossRef]

35. Sambasivan, M.; Fei, N.Y. Evaluation of critical success factors of implementation of ISO 14001 using analytic hierarchy process (AHP): A case study from Malaysia. J. Clean. Prod. 2008, 16, 1424-1433. [CrossRef]

36. Bruno, G.; Esposito, E.; Genovese, A.; Passaro, R. AHP-based approaches for supplier evaluation: Problems and perspectives. J. Purch. Supply Manag. 2012, 18, 159-172. [CrossRef]

37. Glock, C.H.; Grosse, E.H.; Ries, J.M. Decision support models for supplier development: systematic literature review and research agenda. Int. J. Prod. Econ. 2017, 193, 798-812. [CrossRef]

38. Fallahpour, A.; Udoncy Olugu, E.; Nurmaya Musa, S.; Yew Wong, K.; Noori, S. A decision support model for sustainable supplier selection in sustainable supply chain management. Comput. Ind. Eng. 2017, 105, 391-410. [CrossRef]

39. Saaty, T.L. Decision making with the analytic hierarchy process. Int. J. Serv. Sci. 2008, 1, 83. [CrossRef]

40. Subramanian, N.; Ramanathan, R. A review of applications of analytic hierarchy process in operations management. Int. J. Prod. Econ. 2012, 138, 215-241. [CrossRef]

41. Goepel, K.D. Implementation of an online software tool for the analytic hierarchy process-Challenges and practical experiences. Int. Symp. Anal. Hierarchy Process 2017, 10, 1-20.

42. Talib, F.; Rahman, Z.; Qureshi, M.N. Pareto analysis of total quality management factors critical to success for service industries. Int.J. Qual. Res. 2010, 4, 155-168.

43. Cervone, $\mathrm{H}$. Applied digital library project management: Using pareto analysis to determine task importance rankings. OCLC Syst. Serv. 2009, 25, 76-81. [CrossRef]

(C) 2019 by the authors. Licensee MDPI, Basel, Switzerland. This article is an open access article distributed under the terms and conditions of the Creative Commons Attribution (CC BY) license (http:/ / creativecommons.org/licenses/by/4.0/). 